\title{
Ophthalmic manifestations of congenital protein $C$ deficiency: a case report and mini review
}

Fariba Ghassemi ${ }^{1,2,3^{*}}$, Fatemeh Abdi ${ }^{4,1}$ and Mandana Esfahani ${ }^{1}$

\begin{abstract}
Background: Homozygous protein C (PC) deficiency is a potentially fatal disease with ocular blinding presentation or sequela.

Case presentation: A 5 month-old boy was presented for evaluation of leukocoria. He had a history of frequent bruises and PC deficiency, treated with warfarin.

His intraocular pressure was normal. In the left eye leukoma with anterior segment dysgenesis, shallow anterior chamber, and cataract were observed. Fundus was not visible. B-scan revealed a closed funnel retinal detachment. His right eye had a normal anterior segment and a thin retina with anomalous retinal vascular branching at equator and peripheral retina. A fibrovascular tuft on the optic nerve head with induced traction on superior arcade was visible. Total loss of $a$ and $b$ wave of both were appreciated in electroretinography (ERG). Fluorescein angiography (FA) showed very severe leakage at the junction of the vascularized and non-vascularized retina and optic nerve head. Favorable outcome was achieved with lasering of avascular retina in the right eye.
\end{abstract}

Conclusion: The potential for protein C deficiency should be assessed in all infants with leukocoria, anterior segment dysgenesis, retinal detachment and retinal dysplasia. Early diagnosis could save the child's life and vision.

Keywords: Protein C deficiency, Congenital, Ophthalmic manifestations, Retinal detachment, Retinal dysplasia

\section{Background}

Protein C (PC), first described by Stenflo in 1976, is a vitamin $\mathrm{K}$ dependent anticoagulant enzyme that inactivates the plasma factors Va and VIIIa by limited proteolysis, thereby inhibiting the conversion of factor $\mathrm{X}$ to factor Xa and of prothrombin to thrombin [1]. Hereditary (congenital) PC deficiency is a rare autosomal disorder that predisposes to potentially blinding and fatal thromboembolic attacks [2]. Homozygotes have very low or undetectable PC activity (usually less than $1 \%$, normal

\footnotetext{
* Correspondence: fariba.ghassemi@gmail.com

'Eye research center, Farabi Eye Hospital, Tehran University of Medical Sciences, Qazvin Square, Tehran, IR, Iran

${ }^{2}$ Retina \& Vitreous Service, Farabi Eye Hospital, Tehran University of Medical Sciences, Tehran, IR, Iran

Full list of author information is available at the end of the article
}

70-140\%) and do present within the first few days of life [2]. Heterozygotes have about $50 \%$ levels of PC and usually remain asymptomatic until adolescence or adulthood. Neonatal PC deficiency may also be acquired and transient, especially in preterm ill infants [3] with subsequent thrombosis being as severe as in the homozygous condition. Herein, we present a case of congenital PC deficiency with asymmetric ophthalmic manifestations. Fluorescein angiography (FA) and electroretinography (ERG) have been performed. The better eye was treated with indirect laser and the vision was saved.

\section{Case presentation}

The patient was a full term Iranian male that was delivered with normal labor and was the first child of first 
cousin parents. He was presented on his third day of life with a purpura area on his buttocks and abdomen.

Very low protein C activity (less than $8 \%$ ) was confirmed in the laboratory investigations and the patient was treated with fresh frozen plasma (FFP) and anticoagulant therapy (warfarin).

Both parents had low level of PC activity (52\% in father and $60 \%$ in mother.). Liver and renal function tests were normal and no organomegaly or lymphadenopathy was observed. After 5 months, in his first ophthalmic examination, leukocoria was detected and evaluated. The child was on warfarin therapy with no more hypercoagulability state. The examination under anesthesia was conducted at Farabi Hospital for further assessment.

Both eyes had normal intraocular pressure (IOP). He had eye-to-eye contact in the right eye but he couldn't fix and follow in left eyes.

His right eye had a normal anterior segment with round and reactive pupil. $\mathrm{He}$ had a central corneal leukoma on his left eye with a distorted pupil, total posterior synechia, dilated iris radial vessels, flat anterior chamber and mature membranous cataract. The right eye had a normal anterior segment, on a fundoscopy, a thin retina with anomalous retinal vascular branching and fading arterioles and venules was observed at equator and thereafter. (Fig. 1, a-h) There was a fibrovascular tuft on the optic nerve head with an induced traction on superior arcade. At the B-scan, the left eye had a closed funnel shaped retinal detachment. Electroretinography (ERG) elucidated complete loss of a and $b$ wave of both eyes. Fluorescein angiography (FA) has shown very severe leakage at the vascularized and non-vascularized borders of the fundus and at the optic nerve head of the right eye. Severe patchy and stippled abnormal skin fluorescence (on the face, thorax, back, buttocks, and limbs) was observed at the time of FA. (Fig. 1, d-h) Indirect laser has been applied to the avascular areas.

The skipped areas were lasered during consecutive monthly follow-up visits and the neovascularizations were gone. The patient was followed-up for a total of 28 months with a favorable outcome, as no new ocular or

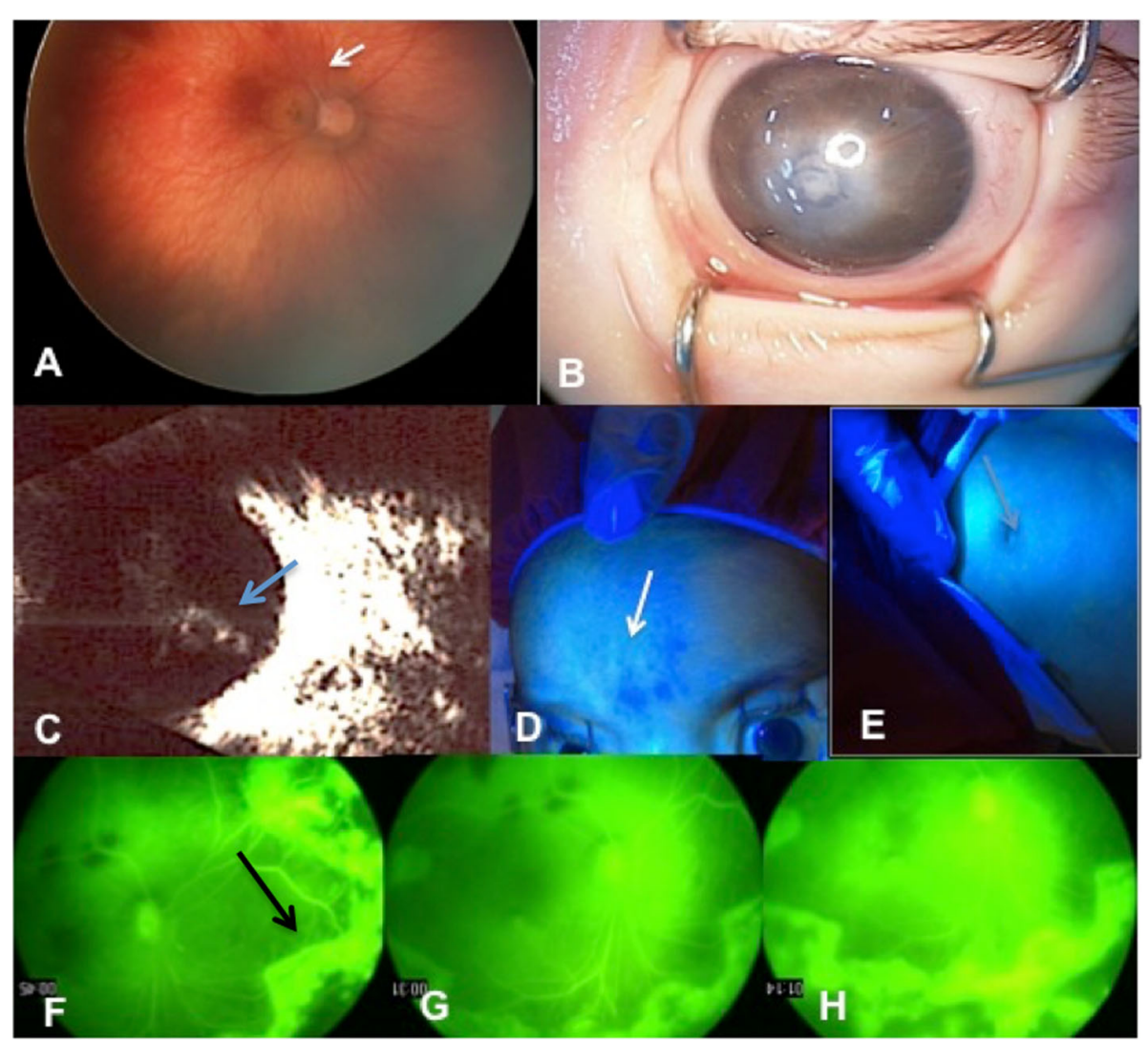

Fig. 1 Ocular findings of a patient with homozygous congenital protein C deficiency. a In the right eye thin dysplastic retina and peripheral avascularization with a fibrovascular band from optic disc to superior arcade is visible (arrow). b In the left eye leukoma and irregular pupil with posterior synechia and dilated iris vessels and cataract is visible. c Total funnel shaped retinal detachment of left eye is visible in B-scan (arrow). $\mathbf{d}$ and e Splinter and patchy abnormal fluorescences of the skin at the time of fluorescein angiography are shown (arrow). f-h Fluorescein angiography with early leakage (arrow) from mid-peripheral vessels all over the retina and later leakage around the optic nerve head due to the tractional effect of fibrovascular band. The leakage increases during less than 1 min with severe vitreous fluorescence 
Table 1 Review of the reported ocular problems in Congenital Protein C deficiency

\begin{tabular}{|c|c|c|c|c|c|}
\hline Report & $\begin{array}{l}\text { Reported } \\
\text { cases }\end{array}$ & $\begin{array}{l}\text { Involved } \\
\text { eye }\end{array}$ & $\begin{array}{l}\text { Anterior segment } \\
\text { involvement }\end{array}$ & Posterior segment involvement & Global involvement \\
\hline $\begin{array}{l}\text { Estelles A } \\
\text { et al [1984] } \\
\text { [6] }\end{array}$ & 1 & $\mathrm{OU}$ & & $\begin{array}{l}\text { Bilateral vitreous hemorrhage and } \\
\text { intravitreal mass }\end{array}$ & \\
\hline $\begin{array}{l}\text { Marciniak E } \\
\text { et al. [1985] } \\
\text { [7] }\end{array}$ & 1 & OU & $\begin{array}{l}\text { Corneal opacity Case1: } \\
\text { Corneal opacity, pupil not } \\
\text { visible in one eye } \\
\text { Case2: Bilateral cataract, }\end{array}$ & $\begin{array}{l}\text { Case 1: Vitreous opacity in one eye } \\
\text { Case 2: total retinal detachment with } \\
\text { retinal new and old hemorrhages }\end{array}$ & Microphthalmia \\
\hline $\begin{array}{l}\text { Rappaport } \\
\text { ES et al. } \\
\text { [1987] [8] }\end{array}$ & 1 & OU & & Hyperplastic vitreous bilaterally & \\
\hline $\begin{array}{l}\text { Pulido JS } \\
\text { [1987] [9] }\end{array}$ & 1 & OU & $\begin{array}{l}\text { Prominent iris vessels, } \\
\text { shallow anterior chamber, } \\
\text { synechia, cataract, retrolental } \\
\text { membrane }\end{array}$ & $\begin{array}{l}\text { Bilateral vitreal hemorrhage, and funnel- } \\
\text { shaped retinal detachment in both eyes }\end{array}$ & \\
\hline $\begin{array}{l}\text { Auletta MJ } \\
\text { and } \\
\text { Headington } \\
\text { JT [1988] } \\
{[10]}\end{array}$ & 1 & OU & $\begin{array}{l}\text { Raised intraocular pressure, } \\
\text { flattened anterior chambers, } \\
\text { iris atrophy, lens adhesions }\end{array}$ & Bilateral retinal detachment & Bilateral leukocoria \\
\hline $\begin{array}{l}\text { Hartman KR } \\
\text { [1989] [11] }\end{array}$ & 1 & $\mathrm{OU}$ & & Vitreal eye hemorrhages and & Intraparenchymal brain infarction \\
\hline $\begin{array}{l}\text { Hermsen } \\
\text { VM et al } \\
\text { [1990] [12] }\end{array}$ & 1 & $\mathrm{OU}$ & $\begin{array}{l}\text { Vascularized lens, non- } \\
\text { existent anterior chambers }\end{array}$ & $\begin{array}{l}\text { Funnel-shaped retrolental mass, normal } \\
\text { retina and optic nerve }\end{array}$ & Bilateral PHPV, microphthalmos \\
\hline $\begin{array}{l}\text { Soria JM } \\
\text { et al. [1985] }\end{array}$ & 1 & & & Persistence of primary vitreous & Microphthalmia, irregular globe \\
\hline
\end{tabular}

et al. [1985]

[13]

Cassels-
Brown A
et al. [1994]

Case 1: Posterior embryotoxon, shallow anterior chambers, ectropion uvea, posterior synechia Case 2: marked periorbital edema and hemorrhagic conjunctival chemosis et al. [1994] [15]

Dreyfus M 9

et al. [1995] [16]

Hattenbach 2

LO et al.

[1999] [5]

Ergenekon 1

E et al.

[2000] [17]

Churchill AJ 2

et al. [2001]

[18]

Paysse EA 1

[2002] [19]
OU

Flat anterior chamber
Case 1. Shallow anterior chamber

Case 2. Shallow anterior chamber, posterior synechia

Case2. Right leukocoria
Case 1: subconjunctival hemorrhage, a right sided retinal arterial occlusion and bilateral florid retinal hemorrhages with swollen hemorrhagic optic discs secondary to retinal venous occlusions, vitreous hemorrhages retinal detachment in one eye

Case 2: hazy media, minor bilateral vitreous hemorrhages, and minor right sided retinal hemorrhage

Bilateral recurrent ischemic optic neuropathy

Case 1. Left retrolental opacities, funnel retinal detachment, vitreous hemorrhage

Case 2. Right vitreous hemorrhage, funnel retinal detachment

Eye ultrasound revealed an 10x7 mm hyperechogenic structure underneath. Retina of the left eye consistent with subretinal hemorrhage

Case 1. Bilateral central retinal vein occlusions, vitreous hemorrhage, and a right central retinal artery occlusion Case 2. Total retinal detachment and a left macular hemorrhage

Bilateral retinal detachment, fibrotic hyaloid arteries
Case 1:

Strabismus, nystagmus, leukocoria Case 2: early birth 25 wk., end up to death at 23 days of life because of some subarachnoid hemorrhage and with worsening lung function

Association with Protein S deficiency, antithrombin III

Unilateral or bilateral blindness 6/9 cases bilateral PHPV

Case 1. Strabismus, microphthalmos Case 2. Microphthalmos

Leukocoria 
Table 1 Review of the reported ocular problems in Congenital Protein C deficiency (Continued)

\begin{tabular}{|c|c|c|c|c|c|}
\hline Report & $\begin{array}{l}\text { Reported } \\
\text { cases }\end{array}$ & $\begin{array}{l}\text { Involved } \\
\text { eye }\end{array}$ & $\begin{array}{l}\text { Anterior segment } \\
\text { involvement }\end{array}$ & Posterior segment involvement & Global involvement \\
\hline $\begin{array}{l}\text { Sirachainan } \\
\text { N et al } \\
\text { [2003] [20] }\end{array}$ & 2 & OU & & & $\begin{array}{l}\text { Preserving eye function, high myopia, } \\
\text { cerebral palsy }\end{array}$ \\
\hline $\begin{array}{l}\text { Park UC } \\
\text { et al. [2005] } \\
{[21]}\end{array}$ & 1 & OU & $\begin{array}{l}\text { Bilateral corneal opacity, } \\
\text { microphthalmia, posterior } \\
\text { synechia, pupillary } \\
\text { membrane, shallow anterior } \\
\text { chamber }\end{array}$ & $\begin{array}{l}\text { Vitreoretinopathy suggesting, PHPV, } \\
\text { intravitreal masses, funnel-shaped retinal } \\
\text { detachment with bilateral retinal } \\
\text { dysplasia }\end{array}$ & $\begin{array}{l}\text { Bilateral leukocoria, no } \\
\text { microphthalmos, blind OU }\end{array}$ \\
\hline $\begin{array}{l}\text { de Lemus- } \\
\text { Varela ML } \\
\text { [2005) }[22]\end{array}$ & 1 & OU & & Vitreous hemorrhage & \\
\hline $\begin{array}{l}\text { Douglas AG } \\
\text { et al. [2010] } \\
{[23]}\end{array}$ & 1 & OU & No red reflex OU & $\begin{array}{l}\text { Vitreoretinal dysplasia, severe hazy } \\
\text { media in one eye and OU PFV }\end{array}$ & $\begin{array}{l}\text { Leukocoria OS, bilateral } \\
\text { microphthalmia, deranged VEP, poor } \\
\text { vision, nystagmus }\end{array}$ \\
\hline $\begin{array}{l}\text { Wang BZ } \\
{[2012][24]}\end{array}$ & 1 & OU & & $\begin{array}{l}\text { Macular hypoplasia with blond retinal } \\
\text { background }\end{array}$ & $\begin{array}{l}\text { Doll's eye movements, no fix and } \\
\text { follow movement of the eyes, ponto- } \\
\text { cerebellar hypoplasia, nystagmus, stra- } \\
\text { bismus, Flat ERG }\end{array}$ \\
\hline $\begin{array}{l}\text { Desai S } \\
\text { et.al. [2014] } \\
{[25]}\end{array}$ & 1 & OU & & $\begin{array}{l}\text { Combined central retinal venous and } \\
\text { arterial obstruction }\end{array}$ & $\begin{array}{l}\text { Severe Type II protein C deficiency } \\
\text { with factor V Leiden mutation, } \\
\text { Glaucoma }\end{array}$ \\
\hline $\begin{array}{l}\text { Almarzouki } \\
\text { HS et al } \\
\text { [2016] [26] }\end{array}$ & 2 & OU & Peter's anomaly & & \\
\hline $\begin{array}{l}\text { Baothman } \\
\text { AA et al. } \\
\text { [2017] [27] }\end{array}$ & 5 & $\mathrm{OU}$ & $\begin{array}{l}\text { Peter's anomaly, corneal } \\
\text { opacity }(3 / 5)\end{array}$ & $\begin{array}{l}\text { Blindness ( } 4 / 5 \mathrm{OU}) \text {, ocular hemorrhage } \\
\text { shortly after birth resulted in visual loss } \\
(1 / 5)\end{array}$ & \\
\hline $\begin{array}{l}\text { Present } \\
\text { study }\end{array}$ & 1 & OU & $\begin{array}{l}\text { Left eye shallow anterior } \\
\text { chamber, cataract, leukoma, } \\
\text { posterior synechia }\end{array}$ & $\begin{array}{l}\text { Dysplastic retina and total retinal } \\
\text { detachment in the other eye }\end{array}$ & Flat ERG, fluorescent spots \\
\hline
\end{tabular}

ERG Electroretinography, OD Right eye, OS Left eye, OU Both eyes, PHPV Persistent primary hyperplastic vitreous

systemic findings were detected. He had eye-to-eye contact and fix and follow vision in the right eye but no fix and follow vision in the left eye.

\section{Discussion and conclusions}

Herein, we described a case of homozygote PC deficiency with severe asymmetric anterior and posterior segment dysgenesis. His right eye was rescued from the inevitable blindness of the future. The disadvantages of this report include the poor co-operation during ERG and FA (due to a young age) and the lack of genetic testing.

Activated PC prevents the formation of blood clots by down-regulating the coagulation cascade and blocking the spread of thrombosis [4]. Phenotypically, two types of PC deficiency have been described: type I, with reduced both antigenic and functional levels, and type II deficiency with reduced PC activity and normal antigenic concentration. Type I heterozygous cases comprise $76 \%$ of cases and homozygous type I comprise only $5 \%$ of cases with severe ocular and systemic findings. ${ }^{4}$ Homozygous PC deficiency is rare with an estimated incidence of 1 in 500,000 to 1 in 750,000 [4]. It presents $2 \mathrm{~h}$ to months after birth, or with delayed symptoms, with life threatening thromboses involving the central nervous system, eyes, kidneys, and skin (purpura fulminans) [5]. Management is carried out in the acute phase with intravenous PC concentrate (ImmunoAG, Vienna, Austria), FFP and anticoagulators [5]. Untreated cases usually lead to death [5].

Ophthalmic manifestations include non-reactive pupils, leukocoria, chemosis, periorbital edema, shallow anterior chamber, dilated iris vessels, posterior synechia and microphthalmos. Posterior segment findings include vitreous, retinal and subretinal hemorrhage, retinal arterial and venous occlusion and retinal dysplasia [2].

One or both of the eyes may be affected. (Table 1) Leukocoria alone may be the first manifestation of homozygous PC deficiency, even before any other systemic manifestations such as purpura fulminans [17]. Early treatment may result in a better visual prognosis [17]. Likewise, homozygous PC deficiency can lead to thrombosis of the cavernous sinus and other cranial 
vessels [28]. These ocular complications may occur as antenatal or postnatal events [28].

Systemic manifestations are purpura fulminans, hematomas; epistaxis; prolonged bleeding; hydrocephalus; subarachnoid hemorrhage; pulmonary embolism; thrombotic hemorrhagic gastrointestinal and genitourinary mucosal infarctions of renal and deep vein thrombosis with the pulmonary embolism and candida sepsis [28]. These lesions usually cause death if they are not treated.

Approximately 20 case reports of PC deficiencies with ocular involvement have been published since the first patient was described in 1981. (Table 1).

The casual association of PC deficiency and retinal dysplasia may be the case in our patient. A thrombosis of the fetal hyaloid arterial system and partial or complete microvascular occlusions at a crucial developmental stage may underlie the developmental eye pathology. Our patient had bilateral asymmetric involvement, and more specifically, avascularization and peripheral vascular leakage in the better eye and total funnel detachment in the other eye. This is the third bilateral asymmetric case reported and the only case with fluorescein angiography. The interesting problem in our case was the patchy severe fluorescence of some parts of the skin that was observed at the time of fluorescein angiography. Lasering of the avascular retina prevented the baby from being completely blind. Mosnier et al. documented the additional effect of protein $C$ in on the cytoprotective pathway mediated by a separate mechanism than its anticoagulant role [29]. Maintaining the endothelial barrier and anti-apoptotic activity of the PC in this pathway [29] and vascularization arrest of retina may have some effects on retinal dysplastic changes. In some of the described patients, persistent primary hyperplastic vitreous (PHPV) and microphthalmia have been reported. (Table 1) Vitreoretinopathy in both eyes proposed retinal dysplasia rather than PHPV [21]. Depending on the time at which vascular insults occur within the ocular system during the embryonic developmental phase, different presentations of the anterior segment and /or posterior segment would follow. Despite complete treatment, the process of ocular changes could be progressive as seen in corneal opacity [21]. Wang et al. reported association of PC deficiency with other hypercoagulability states as protein $\mathrm{S}$ and antithrombin III deficiency, as well as borderline hypothyroidism [24]. We have not seen such an association.

We therefore conclude that unilateral or bilateral infantile ocular findings such as leukocoria and retinal detachments and dysplasia may be the first manifestations of homozygous PC deficiency. In addition, by paying attention to the possible asymmetric nature of the ocular manifestation, vision can be protected to some degree. Physicians should be aware of these problems, as these infants may also have severe cerebral and internal vital organ complications that are preventable, if they are treated on time. The possible effect of natural blood anticoagulants (such as PC) on the development of the anterior and posterior segments of the eye during or after fetal development has yet to be defined.

\section{Abbreviations \\ ERG: Electroretinography; FFP: Fresh frozen plasma; PC: Protein C; PHPV: Persistent primary hyperplastic vitreous}

\section{Acknowledgements}

Not applicable.

\section{Authors' contributions}

FG: Hypothesis creation, intervention application, data collection, and/or article writing. FA: Data collection, and/or article writing. ME: Data collection, and/or article writing. All authors have read and approved the manuscript.

\section{Funding}

No funding was received by any of the authors for writing this manuscript.

\section{Availability of data and materials}

All data generated or analyzed during this study are included in this published article.

\section{Ethics approval and consent to participate}

This study complied with the tenets of the Declaration of Helsinki. IRB approval (TUMS ethic committee- Farabi Hospital) was exempted because this was a single case report. Informed consent was given.

\section{Consent for publication}

Written informed consent for publication of his clinical details and clinical images was obtained from the patient's parents.

\section{Competing interests}

The authors declare that they have no competing interests.

\section{Author details}

${ }^{1}$ Eye research center, Farabi Eye Hospital, Tehran University of Medical Sciences, Qazvin Square, Tehran, IR, Iran. ${ }^{2}$ Retina \& Vitreous Service, Farabi Eye Hospital, Tehran University of Medical Sciences, Tehran, IR, Iran. ${ }^{3}$ Department of Ophthalmology, Farabi Hospital Medical University Hospital, Tehran University of Medical Sciences, Tehran, IR, Iran. ${ }^{4}$ Department of Ophthalmology, Rasoul Akram Hospital, Iran University of Medical Sciences, Tehran, IR, Iran.

Received: 27 September 2019 Accepted: 6 April 2020

Published online: 13 July 2020

\section{References}

1. Clouse $\mathrm{LH}$, Comp PC. The regulation of hemostasis: the protein C system. N Engl J Med. 1986;314:1298-304.

2. Marlar RA, Montgomery RR, Broekmans AW. Diagnosis and treatment of homozygous protein C deficiency. J Pediatric. 1989;114:528-34.

3. Manco-Johnson MJ, Marlar RA, Jacobson LJ, Hays T, Warady BA. Severe protein C deficiency in newborn infants. J Pediatric. 1988;113:359-63.

4. Knoebl PN. Severe congenital protein C deficiency: the use of protein C concentrates (human) as replacement therapy for life-threatening bloodclotting complications. Biologics. 2008;2:285-96.

5. Hattenbach LO, Beeg T, Kreuz W, Zubcov A. Ophthalmic manifestations of congenital protein C deficiency. J AAPOS. 1999;3:188-90.

6. Estellés A, Garcia-Plaza I, Dasí A, Aznar J, Duart M, Sanz G, et al. Severe inherited "homozygous" protein C deficiency in a newborn infant. Thromb Haemost. 1984;52:53-6.

7. Marciniak E, Wilson HD, Marlar RA. Neonatal purpura fulminans: a genetic disorder related to the absence of protein C in blood. Blood. 1985;65:15-20. 
8. Rappaport ES, Speights VO, Helbert B, Trowbridge A, Koops B, Montgomery RR, et al. Protein C deficiency. South Med J. 1987:80:240-2.

9. Pulido JS, Lingua RW, Cristol S, Byrne SF. Protein C deficiency associated with vitreous hemorrhage in a neonate. Am J Ophthalmol. 1987;104:546-7.

10. Auletta MJ, Headington JT. Purpura fulminans. A cutaneous manifestation of severe protein C deficiency. Arch Dermatol. 1988;124:1387-91.

11. Hartman KR, Manco-Johnson M, Rawlings JS, Bower DJ, Marlar RA. Homozygous protein $C$ deficiency: early treatment with warfarin. Am J Pediatr Hematol Oncol. 1989;11:395-401.

12. Hermsen VM, Conahan JB, Koops BL, Cunningham RD. Persistent hyperplastic primary vitreous associated with protein C deficiency. Am J Ophthalmol. 1990;109:608-9.

13. Soria J, Soria C, Samama M, Nicolas G, Kisiel W. Severe protein C deficiency in congenital thrombotic disease--description of an immunoenzymological assay for protein C determination. Thromb Haemost. 1985:53:293-6.

14. Cassels-Brown A, Minford AMB, Chatfield SL, Bradbury JA. Ophthalmic manifestations of neonatal protein C deficiency. Br J Ophthalmol. 1994;78: 486-7.

15. Acheson JF, Sanders MD. Coagulation abnormalities in ischaemic optic neuropathy. Eye. 1994;8:89-92.

16. Dreyfus M, Masterson M, David M, Rivard GE, Müller FM, Kreuz W, Beeg T, Minford A, Allgrove J, Cohen JD, et al. Replacement therapy with a monoclonal antibody purified protein C concentrate in newborns with severe congenital protein C deficiency. Semin Thromb Hemost. 1995;21: 371-81.

17. Ergenekon E, Solak B, Öztürk G, Atalay Y, Koç E. Can leucocoria be the first manifestation of protein C deficiency? Br J Ophthalmol. 2000;84:117-21.

18. Churchill AJ, Gallagher MJ, Bradbury JA, Minford AM. Clinical manifestations of protein $\mathrm{C}$ deficiency: a spectrum within one family. $\mathrm{Br} J$ Ophthalmol. 2001:85:241-2

19. Paysse EA, McCreery KM, Coats DK. Surgical management of the lens and retrolenticular fibrotic membranes associated with persistent fetal vasculature. J Cataract Refr Surg. 2002:28:816-20.

20. Sirachainan N, Chuansumrit A, Hanutsaha P, Pakakasama S, Hongeng S. Preserving eye function in prematurely born children with severe protein $\mathrm{C}$ deficiency. J Thromb Haemost. 2003;1 (8):1858-9.

21. Park UC, Choung HK, Kim SJ, Yu YS. Bilateral retinal dysplasia and secondary glaucoma associated with homozygous protein C deficiency. Korean J Ophthalmol. 2005;19:112-5.

22. de Lemus-Varela ML, Arriaga-Dávila Jde J, PatriciaSalinas-López M. Protein C congenital deficiency. A case report. Gac Med Mex. 2005;141(3):229-31.

23. Douglas AG, Rafferty H, Hodgkins P, Nagra A, Foulds NC, Morgan M, Temple IK. Persistent fetal vasculature and severe protein $\mathrm{C}$ deficiency. Mol Syndromol. 2010;1:82-6.

24. Wang BZ, Siriwardana P, Taranath D. Macular hypoplasia in congenital disorder of glycosylation type ia. Case Rep Ophthalmol. 2012:3:142-4.

25. Desai S, Rai N, Kulkarni P, Natarajan S. Combined CRVO with CRAO in a patient with protein C deficiency. Retinal Cases \& Brief Reports. 2014;8: 145-9.

26. Almarzouki HS, Tayyib AA, Khayat HA, Alsulami RE, Alzahrani SM, Alkahtani $A S$, et al. Peters anomaly in twins: a case report of a rare incident with novel comorbidities. Case Rep Ophthalmol. 2016;7:186-92.

27. Baothman AA, AlSobhi E, Khayat HA, Alsulami RE, Alkahtani AS, Al-Thobyani AA, et al. A delayed presentation of homozygous protein $C$ deficiency in a series of children: a report on two molecular defects. Clin Case Rep. 2017;5: 315-20.

28. Seligsohn U, Berger A, Abend M, Rubin L, Attias D, Zivelin A, et al. Homozygous protein $C$ deficiency manifested by massive venous thrombosis in the newborn. N Engl J Med. 1984;310:599-62.

29. Mosnier LO, Zlokovic BV, Griffin JH. The cytoprotective protein C pathway. Blood. 2007:109:3161-72.

\section{Publisher's Note}

Springer Nature remains neutral with regard to jurisdictional claims in published maps and institutional affiliations.

Ready to submit your research? Choose BMC and benefit from:

- fast, convenient online submission

- thorough peer review by experienced researchers in your field

- rapid publication on acceptance

- support for research data, including large and complex data types

- gold Open Access which fosters wider collaboration and increased citations

- maximum visibility for your research: over $100 \mathrm{M}$ website views per year

At $\mathrm{BMC}$, research is always in progress.

Learn more biomedcentral.com/submissions 